Addendum

\title{
Addendum: Shinozuka, K. et al. Stem Cell Transplantation for Neuroprotection in Stroke. Brain Sci. 2013, 3, 239-261
}

\author{
Kazutaka Shinozuka, Travis Dailey, Naoki Tajiri, Hiroto Ishikawa, Yuji Kaneko \\ and Cesar V. Borlongan * \\ Center of Excellence for Aging \& Brain Repair, Department of Neurosurgery and Brain Repair, \\ University of South Florida College of Medicine, 12901 Bruce B. Downs Blvd., Tampa, FL 33612, USA; \\ kshinozu@health.usf.edu (K.S.); tdailey@health.usf.edu (T.D.); ntajiri@health.usf.edu (N.T.); \\ hishikaw@health.usf.edu (H.I.); ykaneko@health.usf.edu (Y.K.) \\ * Correspondence: cborlong@health.usf.edu; Tel.: +1-813-974-3988; Fax: +1-813-974-3078
}

Received: 28 October 2017; Accepted: 30 October 2017; Published: 31 October 2017

It has been brought to our attention that the Acknowledgement section is missing in our published paper [1], and therefore we would like to add it as follows:

Acknowledgments: C.V.B. is supported by James and Esther King Foundation for Biomedical Research Program 1KG01-33966 and NIH NINDS RO1 1R01NS071956-01.

This addendum does not cause any changes to results and conclusions in the original published paper.

Conflicts of Interest: The authors declare no conflict of interest.

\section{Reference}

1. Shinozuka, K.; Dailey, T.; Tajiri, N.; Ishikawa, H.; Kaneko, Y.; Borlongan, C.V. Stem Cell Transplantation for Neuroprotection in Stroke. Brain Sci. 2013, 3, 239-261. [CrossRef] [PubMed]

(C) 2017 by the authors. Licensee MDPI, Basel, Switzerland. This article is an open access article distributed under the terms and conditions of the Creative Commons Attribution (CC BY) license (http://creativecommons.org/licenses/by/4.0/). 